\title{
THE INFLUENCE OF DIFFERENT INFORMATION SOURCES ON INNOVATION PERFORMANCE: EVIDENCE FROM FRANCE, THE NETHERLANDS AND CROATIA
}

Mirjana Pejić Bach, Andjelko Lojpur, Sanja Peković, Tatjana Stanovčić

\section{Abstract}

Information sources are considered a catalyst for innovation improvement, and because of this it is particularly important to learn more regarding their impact on innovation performance. Therefore, the goal of this research is to investigate to what extent the usage of different information sources influences internal and external R\&D activities in three countries, Croatia, France and the Netherlands, by employing CIS data, which covers the period from 2006 to 2008. These countries were chosen because of the different levels of their country competitiveness (measured by the Global Competitiveness Index), which permits us to investigate if the usage of information sources has varying impact on their innovation performance. Our results reveal that internal sources, customers, suppliers and universities are important information sources for both internal and external R\&D activities in all three countries. However, significant differences are also found. Firms from the Netherlands (which has the highest country competitiveness) use information sources differently, relying on competitors as one of their most important sources of innovation. On the other hand, the government did not have any impact on firms in Croatia (which has the lowest country competitiveness), indicating that this may be the reason for similar countries lagging behind.

Keywords: information sources, innovation intensity, Croatia, France, Netherlands

JEL: $032, D 83$

\section{INTRODUCTORY REMARKS AND RELATED LITERATURE}

Innovation is today considered one of the main drivers of economic growth. The empirical literature increasingly shows the benefits that firms can obtain from being innovative. Indeed, innovation is considered a strategic tool that helps firms achieve competitive advantage (e.g. Porter, 1990), with innovations in information and communication technology among the most important (Pejić Bach, 2014; Varajão et al., 2009). Consequently, much research has been conducted in order to investigate the drivers of innovation
Mirjana Pejić Bach, PhD

University of Zagreb, Croatia

Faculty of Economics \& Business - Zagreb,

Department of informatics

E-mail:mpejic@efzg.hr

Andjelko Lojpur, $\mathrm{PhD}$

University of Montenegro, Faculty of Economics

E-mail: andjelko@ac.me

Sanja Peković, PhD

University of Montenegro, Faculty of Tourism and

Hotel Management

E-mail: pekovic.sanja@yahoo.fr

Tatjana Stanovčić, PhD

University of Montenegro, Faculty of Tourism and

Hotel Management

E-mail: stanja@ac.me 
in developing countries (e.g. see Lojpur et al., 2015 for comprehensive reviews; Hashi et al., 2013b; Pejić Bach et al., 2013). The most frequently examined factors that influence the level of innovativeness are the size and type of the firm, its industrial sector, group membership, technological opportunities, market share, information sources, degree of competition and its absorptive innovation capacity (Crepon et al.,1998; Kleinknecht \& Mohnen, 2002; Lojpur et al., 2015).

In today's business, firms' innovative activities mainly depend on complementary information sources that can be obtained internally or externally. Scholars argue that firms can achieve significant advantages through the interfirm flow of cross-border knowledge, which can enhance firm innovativeness (Iwasa \& Odagiri 2004). Therefore, among the previously mentioned innovation drivers, information sources are one of the most important (Varis \& Littunen, 2010). Accordingly, competitive advantage is based on open-innovation, in which firms obtain sources of knowledge through a variety of external open pathways (Chesbrough, 2003; Chesbrough, 2006), as well as on social relationships (Leonard \& van Zyl, 2014; Roblek et al., 2013). Through open innovation, firms' activities are based on the sourcing of external knowledge (Chesbrough, 2006; Krotov, 2008). Moreover, networks of customers, suppliers, competitors and other non-market participants are a key source of innovations (de Reuver, 2009, West \& Bogers, 2014). Additionally, by establishing network ties, firms can expand their knowledge and thus enhance their innovation capabilities.

Despite the apparent importance of information sources for innovation, the available studies explore the statistical relationships between certain sources of information and innovation performance, but rarely address if different economic frameworks may influence this relationship. Previous research argues that innovation performance is dependent on institutional frameworks and the various structural characteristics of the national economy (Lojpur et al., 2015). However, research on the impact of information sources on innovation activities is usually conducted on only one country (e.g. Segarra-Blasco \& Arauzo-Carod, 2008). Research conducted on a sample of three and more countries is scarce. One example is the research conducted by Griffith et al. (2006) that revealed that the usage of information sources is somewhat different in France, Germany, Spain and UK.

In our work, we have focused on three countries: the Netherlands, France and Croatia. We have chosen these three countries because they differ according to their competitiveness. As a proxy for country competitiveness, we have used the Global Competitiveness
Index. The Netherlands ranked 8th, France ranked $16^{\text {th }}$ and Croatia ranked $61^{\text {st }}$ according to the Global Competitiveness Report in 2008-2009 (Schwab \& Porter, 2010). In addition, at the time of the research, Croatia was a candidate EU-member country, and a post-communist country, which could be sources of possible differences. Therefore, the choice of these three countries allowed us to shed some light on the possibly variable impact of information sources on the innovation activities in three different countries, measured in internal and external R\&D investments. Such research is scarce, since other authors have compared countries that have similar innovation activities (Griffith et al., 2006). Hashi et al (2013a) compare EU member and candidate countries according to knowledge spillovers, innovation activities, and the competitiveness of their industries, and revealed that substantial differences exist. These studies, however, compare only groups of countries without providing comparison at the individual country level.

Therefore, in order to remedy this lack in the literature, this paper presents an empirical examination of the influence of different information sources on innovation performance in three countries: France, Croatia and the Netherlands. The data are derived from the 'Community Innovation Survey' (CIS8), a cross-sectional survey that covers the period from 2006 to 2008. Using other data sources for comparison of innovation activities is of questionable reliability because of the "substantial discrepancies in the representation of industries from new and old EU member states in the EU market and in the quality of their exports" (Hashi et al., 2013a, p.28). Hence, in our work, we have focused only on the CIS database.

In this research we have investigated the impact of different information sources (internal, market related, and non-market related) on innovative activities. As a proxy for the level of innovative activities, we use two indicators: internal and external R\&D. Internal $R \& D$ indicates if the firm engages in creative work to increase the stock of knowledge for developing new and improved products and processes, while external $R \& D$ indicates if the firm engages with other partners for the purpose of innovative activities. The choice of two dependent variables is related to the theory of knowledge-based innovations, which considers R\&D the main source for new or improved products and processes (Amara and Landry, 2005). This paper will provide important insights into how firms from different countries (with different levels of country competitiveness) perceive and engage in using different information sources as the drivers of innovation activities. The results of our research may help a firm's managers and policy-makers to improve the targeting 
of their policies and strategies for acquiring information as a driver of innovation. At the same time, the results can be beneficial for external agents, such as governmental bodies, universities, consultants, and conferences, who can test if the information that they provide themselves has a positive impact on the innovative activities of firms in the countries where they operate.

In the next section we present a literature review, followed by our empirical strategy. We then discuss our findings. The final section concludes by highlighting the implications and contributions of this research.

\section{LITERATURE REVIEW}

In order to create competitive advantage, firms have to rely on knowledge from different partners. If firms rely only on their internal resources, they will miss important opportunities that various actors could provide them (Chesbrough, 2003). Accordingly, innovation activities present an interactive process involving relationships between firms and different market actors (Yam et al., 2011), since interaction with various sources of information can offer additional assets that are necessary for innovation (Romijn and Albaladejo, 2002). Previous scholars provide arguments that support the positive link between different sources of information and innovation performance. Indeed, it is argued that the ability of firms to absorb knowledge gained through their networks is critical to successful innovation (Cohen \& Levinthal, 1990). Several researchers have investigated different information sources that could impact the innovation activities of firms (e.g. Amara \& Landry, 2005; Leiponen et al., 2011; Herstad et al., 2014). The rationale that links different sources of information and innovation performance is based on the fact that access to a larger variety of sources of information provides firms with more timely information about opportunities for development (Burt, 1992). The following discussion summarizes those arguments.

Internal sources may also have an impact on firm innovation. More precisely, sources inside a firm or Group facilitate the transfer of knowledge that improves innovation performance (Frenz and lettoGillies, 2007; Lojpur et al., 2015).

Market related sources of information, such as customers and suppliers, are considered an important mechanism through which firms improve their innovation activities (Amara and Landry, 2005). Customers are important relationship partners that can provide advantageous information (e.g. competition, new technology, and customer needs). In this sense,
Rothwell (1994) lists the following customer related mechanisms that help firms to improve their level of innovation: complementary knowledge; precise sets of user requirements; sources of solicited information on new/ evolving needs; information on post-launch improvements; and enhancements to the likelihood that innovation will be adopted by other firms within the same user community. Suppliers are also sources of information that provide information sharing generated by their customers and suppliers. Previous scholars confirmed the important role of suppliers for the development of innovation activities (Teubal et al., 1991; Bruce et al., 1995). Information obtained from competitors helps firms to improve their position by diagnostic benchmarking and position advantage building (Day \& Wensle, 1988; Dickson, 1992). Therefore, Lawson and Samson (2001) argue that a firm with superior competitor information can use this knowledge to its advantage by applying its strengths against a rival's weakness and internalize competitors' strengths by imitation and improvement.

Information for innovative activities can be also provided from agents that are not directly related to the market, like consultants, universities, governmental bodies, as well as conferences, trade fairs and exhibitions. Tether \& Tajar (2008) argue that consultants have an important role for innovation in firms, since they can act as sources of external ideas. Moreover, Hargadon \& Sutton (1997) argue that consultants do not create fundamentally new technologies but transfer ideas from one context to another, which itself leads to improved innovation. Since universities are recognized for their abilities to produce highly qualified professionals and cutting edge scientific research, more cooperation between firms and universities could improve the diffusion of knowledge, resulting in greater firm innovation (Janeiro et al., 2013). Cooperation with government provides access to financial resources and information infrastructures, which help firms to become innovative. In the same vein, Amara \& Landry (2005) underline the importance of sources of information from government, indicating that the more sustained and intense the interactions between firms and government, the more these boost innovation performance. Conferences, trade fairs and exhibitions are considered platforms for new products or the promotion of services. Therefore, participation in these events supports knowledge creation and interactive learning (Maskell et al., 2004; Bathelt \& Schuldt, 2008), which advance innovation.

In sum, different sources of innovation are positively associated with innovation activities. Therefore, we test whether information sources from (a) firm itself; (b) customers; (c) suppliers (d) competitors; (e) consultants; 
(f) universities; (g) government; ( $h$ ) and conferences are positively associated with a firm's $R \& D$ activities.

In our model, we also use the following control variables: the size of the company, if the company is part of the group, the market in which the company operates (local, national, EU, other), the most important market of the company (local and national), usage of external funding, and the industry in which the company operates. We presume that the size of the company, if the company is part of the group and has an orientation towards the EU and other markets, as well as funding, should have a positive impact on innovative activities. At the same time, orientation towards local and national markets should have a negative impact, while for the most part the industry in which the company operates should have a neutral effect. Our presumptions regarding the impact of control variables on innovative activities are based on Lojpur et al., (2015).

\section{METHODOLOGY}

\subsection{Data sources}

The data are derived from a cross-sectional survey called the 'Community Innovation Survey,' (CIS8) which covers the period from 2006 to 2008 and is based on the Oslo Manual drawn up by the OECD. The Community Innovation Survey is the result of a significant increase in the importance given to innovation issues at the EU level. The CIS surveys are comprehensive in terms of the range of questionnaire items, including direct measures of innovation performance and a wide variety of factors influencing innovation. The Community Innovation Survey also collects data on the usage of different information sources for innovation (Tether, 2001; Fagerberg et al., 2012). More precisely, CIS tracks the usage of the following information sources as drivers of innovation: firm, suppliers, customers, competitors, consultants, universities, government, and conferences. We use the CIS8 from three countries, France, the Netherlands and Croatia. The CIS8 survey in France is carried out by the Ministry of Economics, Finances and Industry, the data from Netherlands is created by Statistics Netherlands, while in Croatia the CIS8 survey is carried out by the Central Bureau of Statistics. The French sample contains 19,901 observations, the Netherlands sample contains 10,612 observations, and the Croatian sample contains 3,333 observations. CIS data for France and Croatia was obtained from the responsible national bodies for external media (CD), while CIS data for the Netherlands was used in the research on-site at the Statistics Netherlands, Den Haag, the Netherlands during May, 2014.

\subsection{Dependent Variable}

In order to examine the influence of different information sources related to $R \& D$ activities we use two indicators. The first, called R\&D internal, is a binary variable indicating if during the three years from 2006 to 2008 a firm engaged in creative work to increase its stock of knowledge for developing new and improved products and processes. The second, R\&D external, is also a binary variable and measures if during the three years from 2006 to 2008 a firm engaged with other partners in creative work to increase its stock of knowledge for developing new and improved products and processes.

\subsection{Explanatory Variables}

Since firms gain new ideas from a different variety of sources, we use eight dummy variables that represent different types of information sources for a firm's innovativeness. More precisely, we use the variable Firm, which is a binary variable that takes the value 1 if important information sources include the firm itself; Supplier is a binary variable that indicates if a firm's important information sources include suppliers of equipment, materials, components, or software; the variable Customer indicates that customers are among a firm's important information sources; the variable Competitors takes the value 1 if competitors are among a firm's important information sources; Institutions takes the value 1 if institutions are among a firm's important information sources; the binary variable Universities equals 1 if universities are among a firm's important information sources; the variable Government gives us an answer if government is among a firm's important information sources; and finally, Conferences present a binary variable that takes the value 1 if conferences are among a firm's important information sources.

The explanatory variables are:

- Firm itself: During the three years from 2006 to 2008, important information sources included the firm itself; Dummy variable ( $=1$ if yes)

- Supplier: During the three years from 2006 to 2008, important information sources included suppliers of equipment, materials, components, or software; Dummy variable ( $=1$ if yes)

- Customer: During the three years from 2006 to 2008, important information sources included 
customers; Dummy variable ( $=1$ if yes)

- Competitors: During the three years from 2006 to 2008 , important information sources included competitors or other firms in the sector; Dummy variable ( $=1$ if yes)

- Consultants: During the three years from 2006 to 2008 , important information sources included consultants; Dummy variable ( $=1$ if yes)

- Universities: During the three years from 2006 to 2008, important information sources included universities or other higher education institutions; Dummy variable ( $=1$ if yes)

- Government: During the three years from 2006 to 2008, important information sources included government or public research institutes; Dummy variable ( $=1$ if yes)

- Conference: During the three years from 2006 to 2008 , important information sources included conferences, trade fairs, exhibitions; Dummy variable ( $=1$ if yes)

\subsection{Control Variables}

Following previous studies we use several control variables, such as Size, Group, Market, Funding and Sector of Activity, which we found to be important drivers of R\&D activities (e.g. Harris \& Trainor, 2011; Lojpur et al., 2015).

The control variables are:

- Size: Size of the firm; Number of employees, Continuous variable

- Group: Whether belonging to a group; Dummy variable ( $=1$ if yes)

- Local: The firm has sold its products and/or services on the local market during the last three years;
Dummy variable ( $=1$ if yes)

- National: The firm has sold its products and/or services domestically during the last three years; Dummy variable ( $=1$ if yes)

- EU:The firm has sold its products and/or services in other European Union (EU), EFTA or EU candidate countries during the last three years; Dummy variable ( $=1$ if yes)

- Local - the most important market: Local market as the most important market; Dummy variable $(=1$ if yes)

- National - the most important market: National market as the most important market; Dummy variable ( $=1$ if yes)

- Funding: Public funding from local or regional authorities, the central government, the EU, the EU's $6^{\text {th }}$ or $7^{\text {th }}$ Framework Programme for RTD; Dummy variable ( $=1$ if yes)

- Sector of activity: The main activity of the firm is in a particular sector; Dummy variable ( $=1$ if yes)

The variables used in estimation and sample statistics for France, Croatia and Netherlands are presented in Table 1.

\subsection{Empirical strategy}

Following the previous literature, the following econometric specifications are estimated to shed light on information sources that drive cross-country R\&D activities:

$$
Y_{i}^{*}=\alpha+\sum_{i=1}^{16} \beta_{i} X_{i}+\mu_{i}, \quad i=1,2, \ldots, N .
$$

where $X_{i}$ represents the vector of variables for different sources of innovation and controls; $\beta_{1}-\beta_{16}$ are

Table 1: Definition of variables and sample statistics

\begin{tabular}{|l|l|l|l|l|l|l|l|}
\hline \multirow{2}{*}{ Variables } & \multicolumn{2}{|c|}{ France } & \multicolumn{2}{c|}{ The Netherlands } & \multicolumn{2}{c|}{ Croatia } \\
\cline { 2 - 7 } & Mean & SD & Mean & SD & Mean & SD \\
\hline \multicolumn{7}{|c|}{ Dependent variables } \\
\hline R\&D internal (binary 0-1) & 0.23 & 0.42 & 0.18 & 0.39 & 0.19 & 0.39 \\
\hline R\&D external (binary 0-1) & 0.10 & 0.30 & 0.10 & 0.30 & 0.14 & 0.35 \\
\hline \multicolumn{7}{|c|}{ Explanatory variables: Information sources } \\
\hline Firm itself (binary 0-1) & 0.32 & 0.46 & 0.26 & 0.44 & 0.29 & 0.45 \\
\hline Suppliers (binary 0-1) & 0.20 & 0.40 & 0.21 & 0.41 & 0.26 & 0.44 \\
\hline Customers (binary 0-1) & 0.20 & 0.40 & 0.20 & 0.40 & 0.24 & 0.43 \\
\hline Competitors (binary 0-1) & 0.13 & 0.34 & 0.13 & 0.33 & 0.17 & 0.37 \\
\hline Consultants (binary 0-1) & 0.07 & 0.26 & 0.07 & 0.26 & 0.09 & 0.28 \\
\hline Universities (binary 0-1) & 0.05 & 0.22 & 0.05 & 0.22 & 0.07 & 0.25 \\
\hline Government (binary 0-1) & 0.04 & 0.19 & 0.04 & 0.19 & 0.04 & 0.20 \\
\hline $\begin{array}{l}\text { Conferences, trade fairs and exhi- } \\
\text { bitions (binary 0-1) }\end{array}$ & 0.12 & 0.33 & 0.10 & 0.30 & 0.19 & 0.40 \\
\hline
\end{tabular}


Table 1: Continued

\begin{tabular}{|c|c|c|c|c|c|c|}
\hline \multirow[t]{2}{*}{ Variables } & \multicolumn{2}{|c|}{ France } & \multicolumn{2}{|c|}{ The Netherlands } & \multicolumn{2}{|c|}{ Croatia } \\
\hline & Mean & SD & Mean & SD & Mean & SD \\
\hline \multicolumn{7}{|c|}{ Control variables } \\
\hline Size (\# of employees) & 268.56 & 2549.25 & 204.93 & 3314.00 & 127.49 & 441.67 \\
\hline Group (binary 0-1) & 0.63 & 0.48 & 0.54 & 0.50 & 0.26 & 0.44 \\
\hline Local market (binary 0-1) & 0.85 & 0.35 & 0.73 & 0.45 & 0.89 & 0.32 \\
\hline National market (binary 0-1) & 0.58 & 0.49 & 0.68 & 0.46 & 0.50 & 0.50 \\
\hline EU market (binary 0-1) & 0.34 & 0.47 & 0.43 & 0.49 & 0.37 & 0.48 \\
\hline Other market (binary 0-1) & - & - & - & - & 0.28 & 0.45 \\
\hline $\begin{array}{l}\text { Local market - the most impor- } \\
\text { tant (binary 0-1) }\end{array}$ & 0.58 & 0.49 & 0.36 & 0.48 & 0.60 & 0.49 \\
\hline $\begin{array}{l}\text { National market - the most im- } \\
\text { portant (binary } 0-1 \text { ) }\end{array}$ & 0.33 & 0.47 & 0.38 & 0.48 & 0.23 & 0.42 \\
\hline External funding (binary 0-1) & 0.07 & 0.26 & 0.09 & 0.29 & 0.10 & 0.31 \\
\hline Manufacturing (binary $0-1$ ) & 0.29 & 0.45 & - & - & 0.42 & 0.50 \\
\hline Agrifoods (binary 0-1) & 0.06 & 0.23 & - & - & - & - \\
\hline Services (binary 0-1) & 0.23 & 0.42 & - & - & 0.19 & 0.40 \\
\hline Finance (binary 0-1) & 0.02 & 0.15 & - & - & - & - \\
\hline Sales (binary 0-1) & 0.22 & 0.42 & - & - & 0.11 & 0.31 \\
\hline Construction (binary 0-1) & 0.05 & 0.22 & - & - & 0.16 & 0.37 \\
\hline Transport (binary 0-1) & 0.12 & 0.32 & - & - & 0.06 & 0.24 \\
\hline $\begin{array}{l}\text { Food, nutrition \& flowers (binary } \\
0-1 \text { ) }\end{array}$ & - & - & 0.08 & 0.26 & - & - \\
\hline $\begin{array}{l}\text { High tech systems \& materials } \\
\text { (binary } 0-1 \text { ) }\end{array}$ & - & - & 0.13 & 0.34 & - & - \\
\hline Life science (binary 0-1) & - & - & 0.07 & 0.25 & - & - \\
\hline $\begin{array}{l}\text { Main ports \& logistics (binary } \\
0-1 \text { ) }\end{array}$ & - & - & 0.35 & 0.48 & - & - \\
\hline Shipping (binary 0-1) & - & - & 0.07 & 0.25 & - & - \\
\hline Chemical (binary 0-1) & - & - & 0.11 & 0.31 & - & - \\
\hline Creative (binary 0-1) & - & - & 0.13 & 0.34 & - & - \\
\hline Energy (binary 0-1) & - & - & 0.04 & 0.21 & - & - \\
\hline
\end{tabular}

Note: All of the variables are Dummy variables (=1 if yes), except the size which is measured by the number of employees Source: Authors' calculation using CIS8 in France, the Netherlands, Croatia

slope coefficients to be estimated and $\alpha$ and $\mu$ are the intercept and the disturbance term, respectively. The model of firms' R\&D activities is stated as a discretechoice model, with the dummy variables indicating R\&D activities, internal and external, as the dependent variables $Y_{i}$ :

$$
\begin{aligned}
& Y_{i}=1 \quad \text { if } \quad Y_{i}^{*}>0, \\
& Y_{i}=0 \quad \text { otherwise. }
\end{aligned}
$$

We specified logistic distributions for $\mu$ and maximized the log-likelihood of the logit models (Greene, 2003) to estimate the models' parameters up to a positive constant.

\section{RESULTS}

The first goal of the present study is to examine the relationship between different types of sources of innovation on R\&D performance. Tables 2,3 and 4 provide this information.

We can notice from Table 2 that six out of the eight examined sources of information influence positively and significantly internal R\&D activities in French firms. More precisely, only suppliers and competitors are not relevant as sources for a firm's internal R\&D improvement. However, when looking at external $R \& D$ activities, we may conclude that suppliers play a significant role as a source of external R\&D activities. Only competitors are not significantly related to external R\&D activities. Most of the control variables have a significant impact on both internal and external R\&D activities in French firms. However, orientation 
Table 2: The impact of source of innovation on R\&D - French Sample

\begin{tabular}{|c|c|c|c|c|}
\hline & \multicolumn{2}{|c|}{ Internal R\&D } & \multicolumn{2}{|c|}{ External R\&D } \\
\hline & Estimate & SE & Estimate & SE \\
\hline Intercept & $-3.24^{* * *}$ & 0.13 & $-4.65^{* * *}$ & 0.15 \\
\hline \multicolumn{5}{|c|}{ Explanatory variables: Information sources } \\
\hline Firm itself & $3.10^{* * *}$ & 0.07 & $2.41^{* * *}$ & 0.10 \\
\hline Suppliers & -0.03 & 0.06 & $0.25^{* * *}$ & 0.06 \\
\hline Customers & $0.83^{* * *}$ & 0.06 & $0.29 * * *$ & 0.07 \\
\hline Competitors & 0.05 & 0.07 & 0.04 & 0.07 \\
\hline Consultants & $0.24^{* * *}$ & 0.09 & $0.69 * * *$ & 0.07 \\
\hline Universities & $0.62^{* * *}$ & 0.13 & $0.21^{* * *}$ & 0.10 \\
\hline Government & $0.33^{* * *}$ & 0.14 & $0.35^{* * *}$ & 0.11 \\
\hline Conferences, trade fairs, exhibitions & $0.49^{* * *}$ & 0.07 & $0.12^{*}$ & 0.07 \\
\hline \multicolumn{5}{|c|}{ Control variables } \\
\hline Size & $0.00^{* * *}$ & 0.00 & $0.00^{* * *}$ & 0.00 \\
\hline Group & $0.14^{* * *}$ & 0.06 & $0.71^{* * *}$ & 0.06 \\
\hline Local Market & $-0.29 * * *$ & 0.07 & 0.05 & 0.07 \\
\hline National & $0.26^{* * *}$ & 0.08 & 0.07 & 0.10 \\
\hline EU market & $0.41^{* * *}$ & 0.07 & $0.17^{*}$ & 0.09 \\
\hline Local - the most important & $-0.41^{* * *}$ & 0.11 & $-0.31^{* * *}$ & 0.11 \\
\hline National - the most import. & -0.06 & 0.10 & $-0.18^{* *}$ & 0.08 \\
\hline Funding & $1.30^{* * *}$ & 0.10 & $0.83^{* * *}$ & 0.07 \\
\hline Agrifood & 0.02 & 0.11 & $0.31^{* * *}$ & 0.11 \\
\hline Services & $-0.22^{* * *}$ & 0.07 & $-0.38^{* * *}$ & 0.08 \\
\hline Finance & $-0.36^{* * *}$ & 0.15 & -0.19 & 0.16 \\
\hline Commerce & $-1.02^{* * *}$ & 0.08 & $-0.34^{* * *}$ & 0.09 \\
\hline Construction & $-0.95^{* * *}$ & 0.14 & $-0.40^{* * *}$ & 0.17 \\
\hline Transport & -0.01 & 0.11 & $-0.27^{* * *}$ & 0.14 \\
\hline \multicolumn{5}{|c|}{ Tests of global quality } \\
\hline $\begin{array}{l}\text { Test of prediction model (concordant } \\
\text { percentage) }\end{array}$ & \multicolumn{2}{|c|}{94.4} & \multicolumn{2}{|c|}{90.7} \\
\hline Test of global nullity (likelihood ratio) & \multicolumn{2}{|c|}{$1264.73^{* * *}$} & \multicolumn{2}{|c|}{$4718.65^{* * *}$} \\
\hline Number of observations & \multicolumn{2}{|c|}{19901} & \multicolumn{2}{|c|}{19901} \\
\hline
\end{tabular}

Notes: $\left(^{*}\right),\left({ }^{* *}\right)$ and $\left({ }^{* *}\right)$ indicate parameter significance at the 10,5 and 1 percent levels, respectively; Reference for sector activity: manufacturing

Source: Authors' calculation using CIS8 in France

towards the local and national market has a negative effect on both internal and external R\&D.

Turning to the sample from the Netherlands (Table 3 ), the situation is slightly different compared to the French sample. We may notice that, as with the previous results, competitors are not significantly associated with internal $R \& D$ activities, but have a significant impact on external R\&D. Also, the findings suggest that government is not a significant source of $R \& D$ activities (both internal and external) when looking at firms from the Netherlands. In this sense, compared to the French case, where government should continue to provide incentives regarding R\&D, firms in the Netherlands are not dependent on this type of incentive. Furthermore, the impact of conferences, trade fairs and exhibitions disappears when we look at external R\&D activities. Control variables have a weaker effect on innovative activities compared to the French sample. Size does not have any impact, while firms that are part of the group are more active regarding external R\&D. On the other hand, as with the French sample, orientation towards the local market as most important has a negative effect both on internal and external R\&D. It is interesting to note that funding has a negative effect on external $R \& D$. Industry sector is not related to innovativeness, with the one exception of firms from the high technical systems \& materials sector, which are more active 
Table 3: The impact of source of innovation on R\&D - the Netherlands Sample

\begin{tabular}{|c|c|c|c|c|}
\hline & \multicolumn{2}{|c|}{ Internal R\&D } & \multicolumn{2}{|c|}{ External R\&D } \\
\hline & Estimate & SE & Estimate & SE \\
\hline Intercept & $-4.58^{* * *}$ & 0.31 & $-4.81^{* * *}$ & 0.32 \\
\hline \multicolumn{5}{|c|}{ Explanatory variables: Information sources } \\
\hline Firm itself & $2.93^{* * *}$ & 0.12 & $-2.10^{* * *}$ & 0.14 \\
\hline Suppliers & $0.45^{* * *}$ & 0.10 & $0.43^{* * *}$ & 0.10 \\
\hline Customers & $0.81^{* * *}$ & 0.10 & $0.53^{* * *}$ & 0.10 \\
\hline Competitors & -0.09 & 0.10 & $0.45^{* * *}$ & 0.10 \\
\hline Consultants & $0.20 *$ & 0.11 & $1.10^{* * *}$ & 0.10 \\
\hline Universities & $0.46^{* *}$ & 0.16 & $0.93^{* * *}$ & 0.14 \\
\hline Government & 0.13 & 0.18 & -0.17 & 0.16 \\
\hline Conferences, trade fairs, exhibitions & $0.35^{* * *}$ & 0.10 & 0.14 & 0.10 \\
\hline \multicolumn{5}{|c|}{ Control variables } \\
\hline Size & -0.00 & 0.01 & -0.00 & 0.00 \\
\hline Group & 0.05 & 0.09 & $0.35^{* * *}$ & 0.10 \\
\hline Local Market & 0.11 & 0.10 & 0.03 & 0.10 \\
\hline National & $0.27^{* *}$ & 0.14 & 0.04 & 0.15 \\
\hline EU market & $0.22^{* *}$ & 0.11 & $0.20^{*}$ & 0.12 \\
\hline Local - the most important & $-0.33^{* * *}$ & 0.11 & $-0.20^{* *}$ & 0.11 \\
\hline National - the most import. & -0.21 & 0.16 & $-0.27^{*}$ & 0.17 \\
\hline Funding & -0.00 & 0.13 & $-0.26^{* *}$ & 0.12 \\
\hline Food, Nutrition \& Flowers & 0.07 & 0.17 & $0.28^{*}$ & 0.15 \\
\hline High Tech Systems \& Materials & 2.25 & 0.13 & $0.89 * * *$ & 0.10 \\
\hline Life Sciences & 0.33 & 0.30 & 0.14 & 0.30 \\
\hline Main Ports \& Logistics & 0.77 & 0.28 & 0.20 & 0.28 \\
\hline Shipping & 0.13 & 0.30 & 0.22 & 0.31 \\
\hline Chemical industry & -0.53 & 0.28 & -0.14 & 0.28 \\
\hline Creative industry & -0.42 & 0.32 & -0.07 & 0.33 \\
\hline Energy & 0.44 & 0.29 & -0.03 & 0.30 \\
\hline \multicolumn{5}{|c|}{ Tests of global quality } \\
\hline $\begin{array}{l}\text { Test of prediction model (concordant } \\
\text { percentage) }\end{array}$ & \multicolumn{2}{|c|}{95.9} & \multicolumn{2}{|c|}{93.0} \\
\hline Test of global nullity (likelihood ratio) & \multicolumn{2}{|c|}{$2917.66^{* * *}$} & \multicolumn{2}{|c|}{$2912.79 * * *$} \\
\hline Number of observations & \multicolumn{2}{|c|}{10612} & \multicolumn{2}{|c|}{10612} \\
\hline
\end{tabular}

Notes: $\left(^{*}\right),\left({ }^{*}\right)$ and $\left({ }^{* *}\right)$ indicate parameter significance at the 10,5 and 1 percent levels, respectively; Reference for sector activity: manufacturing

Source: Authors' calculation using CIS8 in the Netherlands

regarding external R\&D.

Finally, when looking at Croatian firms, we may say that the important sources for R\&D activities are more similar to those from the Netherlands than they are to the results from France. Table 4 indicates that as with firms from the Netherlands, competitors and government do not positively influence internal R\&D. Moreover, competitors do influence external R\&D, while the relationship is not significant for government and conferences, trade fairs, and exhibitions. Regarding control variables, size has a significant impact on both internal and external R\&D, as well as funding. Also, orientation towards the EU market as well as other markets, positively influences external $R \& D$. Some of industries have a negative effect on innovation activities, such as transport and services.

\section{DISCUSSION}

In order to discuss our findings, a summary of the research is presented in Table 5 . For each of the independent variables the following information is provided: (i) if the independent variable does not have a significant impact, this is stated as None; (ii) if the independent variable does have a significant impact on 
Table 4: The impact of source of innovation on R\&D - Croatian Sample

\begin{tabular}{|c|c|c|c|c|}
\hline & \multicolumn{2}{|c|}{ Internal R\&D } & \multicolumn{2}{|c|}{ External R\&D } \\
\hline & Estimate & SE & Estimate & SE \\
\hline Intercept & $-3.09^{* * *}$ & 0.34 & $-4.29 * * *$ & 0.39 \\
\hline \multicolumn{5}{|c|}{ Explanatory variables: Information sources } \\
\hline Firm itself & $1.93^{* * *}$ & 0.15 & $1.55^{* * *}$ & 0.17 \\
\hline Suppliers & $0.60^{* * *}$ & 0.14 & $0.70^{* * *}$ & 0.15 \\
\hline Customers & $0.80^{* * *}$ & 0.15 & $0.48^{* * *}$ & 0.17 \\
\hline Competitors & 0.13 & 0.14 & $0.31^{* *}$ & 0.15 \\
\hline Consultants & $0.33^{* *}$ & 0.17 & $0.94^{* * *}$ & 0.16 \\
\hline Universities & $0.46^{* *}$ & 0.19 & $0.52^{* * *}$ & 0.19 \\
\hline Government & -0.09 & 0.24 & 0.14 & 0.23 \\
\hline Conferences, trade fairs, exhibitions & $0.48^{* * *}$ & 0.14 & 0.21 & 0.15 \\
\hline \multicolumn{5}{|c|}{ Control variables } \\
\hline Size & $0.00^{* * *}$ & 0.00 & $0.00^{* *}$ & 0.00 \\
\hline Group & -0.05 & 0.14 & -0.01 & 0.15 \\
\hline Local Market & 0.04 & 0.21 & 0.14 & 0.22 \\
\hline National & 0.17 & 0.16 & 0.05 & 0.17 \\
\hline EU market & 0.04 & 0.18 & $0.34^{*}$ & 0.19 \\
\hline Other & 0.14 & 0.17 & $0.40^{* *}$ & 0.18 \\
\hline Local - the most important & 0.02 & 0.22 & -0.13 & 0.23 \\
\hline National - the most import. & 0.20 & 0.22 & -0.19 & 0.23 \\
\hline Funding & $0.41^{* * *}$ & 0.14 & $0.53^{* * *}$ & 0.15 \\
\hline Construction & -0.34 & 0.27 & 0.36 & 0.29 \\
\hline Sales & -0.27 & 0.29 & 0.50 & 0.32 \\
\hline Transport & $-0.74^{* *}$ & 0.35 & 0.12 & 0.38 \\
\hline Services & $-0.77^{* * *}$ & 0.27 & 0.37 & 0.30 \\
\hline \multicolumn{5}{|c|}{ Tests of global quality } \\
\hline $\begin{array}{l}\text { Test of prediction model (concordant } \\
\text { percentage) }\end{array}$ & \multicolumn{2}{|c|}{90.3} & \multicolumn{2}{|c|}{89.0} \\
\hline Test of global nullity (likelihood ratio) & \multicolumn{2}{|c|}{$1211.26^{* * *}$} & \multicolumn{2}{|c|}{$883.44^{* * *}$} \\
\hline Number of observations & \multicolumn{2}{|c|}{3333} & \multicolumn{2}{|c|}{3333} \\
\hline
\end{tabular}

Notes: $\left({ }^{*}\right),\left(^{* *}\right)$ and $\left({ }^{* *}\right)$ indicate parameter significance at the 10,5 and 1 percent levels, respectively; Reference for sector activity: manufacturing

Source: Authors' calculation using CIS8 in Croatia

the dependent variable, $(+)$ or $(-)$ signs are used to indicate the direction of the impact and $1 \%, 5 \%$ or $10 \%$ are used to indicate the level of significance.

The firm itself, when used as an internal source of information for internal R\&D activities, is statistically significant in all three countries, which is in line with the findings of Frenz \& letto-Gillies (2007). The contribution of our research is that relying on internal sources of information is negatively related to external R\&D activities in the Netherlands, which is the highest ranked country according to the Global
Competitiveness Index. This may indicate that firms that invest more in external R\&D activities do not rely on internal sources of innovation in countries with a higher level of competitiveness.

Market-related information sources (suppliers, customers, and competitors) are also investigated. The usage of customers as a source of information has a positive impact both on internal and external R\&D, which confirms research conducted by Rothwell (1994). A similar impact is generated by the usage of suppliers as a source of information, similar to Teubal 
Table 5: Summary of results

\begin{tabular}{|c|c|c|c|c|c|c|}
\hline \multirow[t]{2}{*}{ Variables } & \multicolumn{2}{|c|}{ France } & \multicolumn{2}{|c|}{ Netherlands } & \multicolumn{2}{|c|}{ Croatia } \\
\hline & $\begin{array}{c}\text { R\&D } \\
\text { Internal }\end{array}$ & $\begin{array}{c}\text { R\&D } \\
\text { External }\end{array}$ & R\&D Internal & $\begin{array}{c}\text { R\&D } \\
\text { External }\end{array}$ & R\&D Internal & $\begin{array}{c}\text { R\&D } \\
\text { External }\end{array}$ \\
\hline \multicolumn{7}{|c|}{ Explanatory variables } \\
\hline Firm itself & (+) $1 \%$ & (+) $1 \%$ & (+) $1 \%$ & $(-) 1 \%$ & (+) $1 \%$ & (+) $1 \%$ \\
\hline Suppliers & None & $(+) 1 \%$ & $(+) 1 \%$ & $(+) 1 \%$ & $(+) 1 \%$ & $(+) 1 \%$ \\
\hline Customers & $(+) 1 \%$ & $(+) 1 \%$ & $(+) 1 \%$ & $(+) 1 \%$ & $(+) 1 \%$ & $(+) 1 \%$ \\
\hline Competitors & None & None & None & $(+) 1 \%$ & None & $(+) 5 \%$ \\
\hline Consultants & $(+) 1 \%$ & $(+) 1 \%$ & (+) $10 \%$ & None & $(+) 5 \%$ & $(+) 1 \%$ \\
\hline Universities & $(+) 1 \%$ & $(+) 1 \%$ & $(+) 5 \%$ & $(+) 1 \%$ & $(+) 5 \%$ & $(+) 1 \%$ \\
\hline Government & (+) $1 \%$ & $(+) 1 \%$ & None & None & None & None \\
\hline Conference, fairs and exhibitions & $(+) 1 \%$ & $(+) 10 \%$ & $(+) 1 \%$ & None & $(+) 1 \%$ & None \\
\hline \multicolumn{7}{|c|}{ Control variables } \\
\hline Size & $(+) 1 \%$ & $(+) 1 \%$ & None & None & $(+) 1 \%$ & $(+) 5 \%$ \\
\hline Group & $(+) 1 \%$ & $(+) 1 \%$ & None & $(+) 1 \%$ & None & None \\
\hline Local & $(-) 1 \%$ & None & None & None & None & None \\
\hline National & $(+) 1 \%$ & None & $(+) 5 \%$ & None & None & None \\
\hline EU & $(+) 1 \%$ & (+) $10 \%$ & $(+) 5 \%$ & (+) $10 \%$ & None & $(+) 10 \%$ \\
\hline Other & - & - & - & - & None & $(+) 5 \%$ \\
\hline Local - the most important & $(-) 1 \%$ & $(-) 1 \%$ & $(-) 1 \%$ & $(-) 5 \%$ & None & None \\
\hline National - the most import. & None & (-) $5 \%$ & None & (-) $5 \%$ & None & None \\
\hline Funding & $(+) 1 \%$ & $(+) 1 \%$ & None & $(-) 5 \%$ & $(+) 1 \%$ & $(+) 1 \%$ \\
\hline Agrifoods & None & $(-) 1 \%$ & - & - & - & - \\
\hline Services & $(-) 1 \%$ & $(-) 1 \%$ & - & - & $(-) 1 \%$ & None \\
\hline Finance & $(-) 1 \%$ & None & - & - & - & - \\
\hline Commerce / Sales & $(-) 1 \%$ & (-) $1 \%$ & - & - & None & None \\
\hline Construction & $(-) 1 \%$ & $(-) 1 \%$ & - & - & None & None \\
\hline Transport & None & $(-) 1 \%$ & - & - & $(-) 5 \%$ & None \\
\hline Food, nutrition \& flowers & - & - & None & $(+) 10 \%$ & - & - \\
\hline High tech systems \& materials & - & - & None & $(+) 1 \%$ & - & - \\
\hline Life science & - & - & None & None & - & - \\
\hline Main ports \& logistics & - & - & None & None & - & - \\
\hline Shipping & - & - & None & None & - & - \\
\hline Chemical industry & - & - & None & None & - & - \\
\hline Creative industry & - & - & None & None & - & - \\
\hline Energy & - & - & None & None & - & - \\
\hline \multicolumn{7}{|c|}{ Tests of global quality } \\
\hline $\begin{array}{l}\text { Test of prediction model (con- } \\
\text { cordant percentage) }\end{array}$ & 94.4 & 90.7 & 95.9 & 93.0 & 90.3 & 89.0 \\
\hline $\begin{array}{l}\text { Test of global nullity (likelihood } \\
\text { ratio) }\end{array}$ & $1264.73^{* * *}$ & $4718.65^{* * *}$ & $2917.66^{* * *}$ & $2912.79 * * *$ & $1211.26^{* * *}$ & $883.44^{* * *}$ \\
\hline
\end{tabular}

Notes: None indicates no significant impact, (+) or (-) signs indicate significant impact and $1 \%, 5 \%$ or $10 \%$ are used in order to indicate the level of the significance.

Source: Authors' calculation using CIS8 in France, Netherlands, Croatia

et al.(1991) and Bruce et al.(1995), while France is an exception, since suppliers did not have a significant impact on internal R\&D in companies in that country. The usage of competitors as an information source for internal R\&D does not have a significant impact in any of the countries, which runs contrary to the results of
Day \& Wensle (1988) and Dickson (1992). Our research reveals that having competitors as a source of information has a positive impact in the Netherlands and Croatia only on external R\&D, although the impact in the Netherlands is stronger (significant at 1\%) compared to that of Croatia (significant at 5\%). This may 
indicate that the usage of competitors as a source of information could be a significant generator of country competitiveness, which is the case in the Netherlands. It may also be a significant generator of innovativeness in countries which struggle with competitiveness, such as Croatia.

Information sources that are not related to the market have a mixed impact. Universities have a positive impact on both internal and external R\&D activities. However, firms in the Netherlands report no impact from consultants and conferences, fairs and exhibitions on R\&D external activities, which confirms the findings of Janeiro et al. (2013). Also, government seems to have no impact as an information source for innovative activities for internal R\&D activities among firms in the Netherlands. Moreover, government does not have any impact on internal or external R\&D activities in Croatian firms. A lack of governmental support may be the reason for lower innovative activities in Croatia, which in turns negatively impacts the competitiveness of the country, which confirms the finding of Amara \& Landry (2005). As a result, because of lower competitiveness, governmental information sources remain irrelevant, thus creating a vicious cycle of low innovativeness and low competitiveness in developing countries. On the other hand, governmental sources of information were also irrelevant for companies in the Netherlands, thus indicating that companies in most developed countries do not rely on government, but on other sources of information.

Regarding the control variables, the results are also different across countries. Overall, the control variables in most cases do not have a significant impact on internal or external $R \& D$ in Croatian firms. The usage of funding, as well as orientation towards the EU and other markets, had significant impacts on innovative activities in Croatia. Orientation by the French firms towards local and national markets did not have a significant impact on external R\&D. Size, Group and orientation to the local market did not have a significant impact on R\&D activities in the Dutch firms. To summarize, the control variables had a weaker impact for firms from the Netherlands, as representative of countries with higher country competitiveness, as well for the firms from Croatia, as representative of countries with lower country competitiveness.

In general, the findings suggest that different types of information sources are useful complements to contextual factors in increasing the probability of a firm becoming innovative. Accordingly, to become innovative, firms have to be linked to different market actors through information and knowledge exchange. However, the results also suggest that not all information sources influence innovation activities to the same degree in countries with different overall level of competitiveness. Moreover, based on our results we may also conclude that the overall level of competitiveness and institutional framework matters when examining the relationship between information sources and R\&D capabilities.

\section{CONCLUSION}

R\&D capabilities are important tools for a firm's overall growth that warrant continuing scholarly research. The prior studies on R\&D mainly focus their attention on the firm's characteristics as drivers of a firm's R\&D activities instead of on broader mechanisms that promote R\&D. In order to fill this important gap in the literature, we provide an empirical analysis concerning the relationship between sources of information and R\&D activities. In doing so, we use eight proxies for information sources and we also distinguish between two types of R\&D activities, internal and external. Additionally, in order to consider if institutional framework matters, we test our results using three countries: France, the Netherlands and Croatia. We have chosen these countries because of their different levels of overall competitiveness.

Our results indicate the following. First, it can be concluded that some sources of information have the same impact across the three different countries, irrespective of country competitiveness. Second, companies in the Netherlands, as a representative of countries with high country competitiveness, use information sources in a different manner. In Dutch companies, usage of internal information sources has a negative impact on external R\&D, and the usage of competitors has a positive impact on external R\&D. This could indicate that the most innovative firms in the most developed countries do not rely on internal resources, but instead use competitors as an important source of information for innovative activities. Third, the usage of the government as an information source for innovative activities did not have a significant impact on internal or external R\&D in Croatia, which could be the sources of the lower overall competitiveness of that country. Also, governmental information did not have a significant impact on internal or external R\&D in the Netherlands. In addition, French firms reported that the usage of government sources of information for innovative activities has a positive impact on both internal and external R\&D. Therefore, it may be that governmental support has a reverse U-relationship with innovative activities, making it successful only for countries that are developed, but not among the top ten countries 
according to their competitiveness. Fourth, the results from France are similar to those from Croatia. At first sight, it may be striking that the impact of information sources in France is more similar to its impact in Croatia than in the Netherlands. However, the France is not among the top ten countries in the world regarding country competitiveness as measured by the Global Competitiveness Index. Therefore, our results could indicate that the firms in the top innovative countries (represented by the Netherlands) use information sources in a different manner compared to those of countries that lag behind (represented by France), while the countries that lag behind the most (represented by Croatia) miss government support. Overall, we may conclude that choices of innovation sources have varying effects on R\&D performance from one country to another, and also that companies in countries with different competitiveness levels use information sources in different manners.

Regarding control variables, we can suggest that their impact depends on national context. Size, group, orientation towards national and EU markets and funding have a positive and significant impact on R\&D activities in France. Conversely, only orientation towards national and EU markets as the most important markets positively influence R\&D activities in the Netherlands, as well as the high technical systems \& materials sector. Regarding the case of Croatia, only size and funding significantly influence innovative activities, indicating that in developing economies only large firms that are subsidized by external agents for their innovativeness invest in R\&D.

A number of managerial implications emerge from this research. Identifying the successful sources of innovation may enable managers to define R\&D strategies in relation to their potential sources. Additionally, innovative activities are achieved not only through internal sources, but also through interaction with external knowledge sources. Therefore, managers have to be aware that they have to look outside their immediate environment to boost their firm's innovation activities. Our research also emphasizes that institutional factors are important: matching the broader economic framework to differing types of information sources yields the best outcomes for innovation activity. Governmental sources of information are not efficient both in developing and the most developed countries, thus raising the question of their usability in either context.

Two limitations of the research apply that could be overcome through future analysis. First, future research should focus on the different indictors of innovation in order to propose a more comprehensive conclusion. Additionally, these findings emerge from cross-sectional data collected at one point in time in a limited number of countries. Therefore, a longitudinal approach with more countries in the sample would be welcome in confirming the obtained results.

\section{REFERENCES}

Amara, N., \& Landry, R. 2005. Sources of information as determinants of novelty of innovation in manufacturing firms: evidence from the 1999 Statistics Canada innovation survey. Technovation, 25 (3): 245-259.

Pejić Bach, M. Zoroja, J., \& Vukšić, V. B. (2013). Review of corporate digital divide research: A decadal analysis (20032012). International Journal of Information Systems and Project Management, 1(4): 41-55.

Bathelt, H., \& Schuldt, N. (2008). Between luminaires and meat grinders: International trade fairs as temporary clusters. Regional Studies, 42(6): 853-868.

Bruce, M., Leverick, F., Littler, D., \& Wilson, D. (1995). Success factors for collaborative product development: a study of suppliers of information and communication technology. R\&D Management, 25(1): 33-44.

Burt, R.S. 1992. Structural Holes: The Social Structure of Competition, Harvard University Press, Cambridge, MA.

Chesbrough, H. 2003. Open Innovation: How Companies Actually Do It. Harvard Business Review, 81(7):12-14

Chesbrough, H. 2006. Open innovation: a new paradigm for understanding indus-trial innovation. In: Chesbrough, H., Vanhaverbeke, W., West, J. (Eds.), OpenInnovation: Researching a New Paradigm. Oxford University Press, Oxford, 1-12.

Cohen, J., \& Levinthal, D.A. 1990. Absorptive capacity: A new perspective on learning and innovation. Administrative Science Quarterly, 35(1): 554-571.

Crepon, B., Duguet, E., \& Mairesse, J. 1998. Research, innovation and productivity: an econometric analysis at the firm level. Economics of Innovation and New Technology, 7(2):115-158.

Day, G.S., \& Wensle, R. 1988. Assessing advantage: A framework for diagnosing competitive superiority. Journal of Marketing, 52(2): 1-20.

de Reuver, M., Bouwman, H., \& Maclnnes, I. 2009. Business model dynamics: a case survey. Journal of theoretical and applied electronic commerce research, 4(1): 1-11.

Dickson, P.R. 1992. Toward a general theory of competitive rationality. Journal of Marketing, 56(1): 69-83.

Fagerberg, J., Mowery, D. C., \& Nightingale, P. 2012. Introduction: The heterogeneity of innovationevidence from the Community Innovation Surveys. Industrial and Corporate Change, 21(5): 1175-1180.

Frenz, M., \& letto-Gillies, G. (2009). The impact on innovation performance of different sources of knowledge: Evidence 
from the UK Community Innovation Survey. Research Policy, 38(7): 1125-1135.

Greene,W.H. 2003. Econometric Analysis, 5th Edition. Upper Saddle River, New Jersey: Prenctice Hall.

Griffith, R., Huergo, E., Mairesse, J., \& Peters, B. 2006. Innovation and productivity across four European countries. Oxford Review of Economic Policy, 22(4): 483-498.

Hargadon, A., \& Sutton, R.I. 1997. Technology brokering and innovation in a product development firm. Administrative Science Quarterly, 42(4): 716-749.

Harris, R. \& Trainor, M. 2011. A matching analysis of why some firms in peripheral regions undertake R\&D whereas others do not. Economics of Innovation and New Technology, 20(4): 367-385.

Hashi, I., \& Stojcic, N. (2013a). Knowledge spillovers, innovation activities, and competitiveness of industries in EU member and candidate countries. Economic annals, 58(198): 7-34.

Hashi, I., \& Stojčić, N. (2013b). The impact of innovation activities on firm performance using a multi-stage model: Evidence from the Community Innovation Survey 4. Research Policy, 42(2): 353-366.

Herstad, S. J., Aslesen, H. W., \& Ebersberger, B. 2014. On industrial knowledge bases, commercial opportunities and global innovation network linkages. Research Policy, 43(3): 495-504.

Iwasa, T., \& Odagiri, H. 2004. Overseas R\&D, Knowledge Sourcing, and Patenting: An Empirical Study of Japanese R\&D investment in the US. Research Policy, 33(5): 807-828.

Janeiro, P., Proença, I., \& da Conceição Gonçalves, V. (2013). Open innovation: Factors explaining universities as service firm innovation sources. Journal of Business Research, 66(10): 2017-2023.

Kleinknecht, A., \& Mohnen, P. 2002. Innovation and Firm Performance: Econometric Explorations of Survey Data. Palgrave, Hampshire and New York.

Krotov, V., \& Junglas, I. 2008. RFID as a Disruptive Innovation. Journal of theoretical and applied electronic commerce research, 3(2): 44-59.

Lawson, B., \& Samson, D. 2001. Developing Innovation Capability in Organizations: A Dynamic Capabilities Approach. International Journal of Innovation Management, 5(3): 377-400.

Leiponen, A., \& Helfat, C. E. 2011. Location, decentralization, and knowledge sources for innovation. Organization Science, 22(3): 641-658.

Leonard, A., \& van Zyl, D. (2014). Social relationships in IT project teams: its role, complexity and the management thereof. International Journal of Information Systems and Project Management, 2(1): 21-39.

Lojpur, A., Pejic-Bach, M., \& Pekovic, S. 2015. Determinants of Innovation Intensity in Developed and in Developing Economies: The case of France and Croatia, International
Journal of Innovation Management. Available at: http://www.worldscientific.com/doi/abs/10.1142/ S1363919615500498

Maskell, P., Bathelt, H., \& Malmberg, A. 2004. Temporary clusters and knowledge creation: The effects of international trade fairs, conventions and other professional gatherings. SPACES, 4: 1-34.

Pejić Bach, M. (2014). Exploring Information and Communications Technology Adoption in Enterprises and its Impact on Innovation Performance of European Countries. Ekonomický časopis, 2014(4): 335-362.

Porter M. E. (1990). The Competitive Advantage of Nations, Macmillan, London.

Roblek, V., Pejic Bach, M., Meško, M., \& Bertoncelj, A. (2013). The impact of social media to value added in knowledge-based industries. Kybernetes, 42(4): 554-568.

Romijn, H., \& Albaladejo, M. (2002). Determinants of innovation capability in small electronics and software firms in southeast England. Research policy, 31(7): 1053-1067.

Rothwell, R. 1994. Towards the fifth-generation innovation process. International Marketing Review, 11(7): 7-31.

Schwab, K. \& Porter, M.E. (2010). Global Competitiveness Report 2008-2009. Available at: http://www.weforum. org/pdf/GCR08/GCR08.pdf

Segarra-Blasco, A., \& Arauzo-Carod, J. M. 2008. Sources of innovation and industry-university interaction: Evidence from Spanish firms. Research Policy, 37(8): 1283-1295

Tether, B. 2001. Identifying innovation, innovators and innovative behaviours: a critical assessment of the Community Innovation Survey (CIS). Manchester: Centre for Research on Innovation and Competition, University of Manchester.

Tether, B. S., \& Tajar, A. (2008). Beyond industry-university links: Sourcing knowledge for innovation from consultants, private research organisations and the public science-base. Research Policy, 37(6): 1079-1095.

Teubal, M., Yinnon, T., \& Zuscovitch, E. (1991). Networks and market creation. Research Policy, 20(5): 381-392.

Varajão, J., Trigo, A., \& Barroso, J. (2009). Motivations and trends for it/is adoption: insights from Portuguese companies. International Journal of Enterprise Information Systems (IJEIS), 5(4): 34-52.

Varis, M., \& Littunen, H. 2010. Types of innovation, sources of information and performance in entrepreneurial SMEs. European Journal of Innovation Management, 13(2): 128-154.

West, J., \& Bogers, M. (2014). Leveraging external sources of innovation: a review of research on open innovation. Journal of Product Innovation Management, 31(4): 814-831.

Yam, R., Lo, W., Tang, E. P., \& Lau, A. K. 2011. Analysis of sources of innovation, technological innovation capabilities, and performance: An empirical study of Hong Kong manufacturing industries. Research Policy, 40 (3): 391-402. 